\title{
The associations of polymorphisms of TSH receptor and thyroid hormone receptor genes with L-thyroxine treatment in hypothyroid patients
}

\author{
Sayer I. Al-Azzam, ${ }^{1}$ Karem H. Alzoubi, ${ }^{1}$ Omar Khabour, ${ }^{2}$ Ola Al-Azzeh ${ }^{1}$ \\ ${ }^{1}$ Department of Clinical Pharmacy, Faculty of Pharmacy, Jordan University of Science and Technology; ${ }^{2}$ Department \\ of Medical Laboratory Sciences, Faculty Applied Medical Sciences, Jordan University of Science and Technology; \\ Irbid, Jordan
}

\begin{abstract}
OBJECTIVE: To investigate the possible association between response to levothyroxine (L-T4) doses in hypothyroid patients and variation in thyroid stimulating hormone receptor (TSHR) gene and thyroid hormone receptor (THRa) gene. DESIGN: This cross-sectional correlation study included 228 patients with primary hypothyroidism who were using L-T4 replacement therapy. Thyroid function test was performed using standard techniques. Genotyping of rs939348 of the THR $\alpha$ gene, and rs2268458 and rs2239610 of the TSHR gene was performed using the polymerase chain reaction-based restriction fragment length polymorphism assay (PCR-RFLP). Patient history of illness, medication and compliance data were collected using the patients' medical files. RESULTS: The THR $\alpha$ rs939348 polymorphism was associated with L-T4 replacement doses in hypothyroid patients and in central obesity. No significant correlation was detected between the examined SNPs to TSHR and L-T4 doses or the different clinical and biochemical parameters. Finally, L-T4 dose was associated with lower BMI, waist circumference and TSH, and higher free T4 (fT4) among hypothyroid patients. CONCLUSIONS: Whereas the two tested TSHR polymorphisms were not associated with the dose of T4, the THRa rs939348 polymorphism was associated with L-T4 dose and central obesity among hypothyroid patients. T4 dose was also associated with multiple beneficial effects among hypothyroid patients.
\end{abstract}

Key words: Hypothyroidism, Levothyroxine, Jordan, Thyroid hormone, TSH receptor

\section{INTRODUCTION}

Hypothyroidism is one of the most common endocrine disorders. ${ }^{1}$ It is characterized by underproduc-

\footnotetext{
Address for correspondence:

Dr. Karem Alzoubi, Department of Clinical Pharmacy, Faculty of Pharmacy, Jordan University of Science and Technology, Irbid 22110, Jordan, Tel.: +962-2-720100, Fax: +96227201075, E-mail: khalzoubi@just.edu.jo Received 14-10-2013, Accepted 14-12-2013
}

tion of thyroid hormone ${ }^{2,3}$ which plays an essential physiologic role in the development of the individual and body metabolism. ${ }^{4}$ Hypothyroidism is associated with a wide spectrum of signs, symptoms and long-term complications such as skin manifestations, obesity, hyperlipidemia, bradycardia, fatigue and depression. ${ }^{1-3,5,6}$ Diagnosis and monitoring of hypothyroid patients are based on both clinical evaluation and thyroid function testing., ${ }^{2,7}$ Thyroid stimulating 
hormone (TSH or thyrotropin) is the most sensitive and valuable test of thyroid function and treatment response among patients. ${ }^{2}$

Oral levothyroxine (L-T4) is the drug of choice in the treatment of hypothyroidism. ${ }^{2,3,8-10}$ The goal of therapy is to resolve clinical symptoms and to restore $\mathrm{TSH}$, free T4 (fT4) and free T3 (fT3) to normal ranges. ${ }^{2,3}$ The average daily L-T4 replacement dose that is needed to control hypothyroid adults is 1.7 $\mathrm{mcg} / \mathrm{kg}$ of body weight (ideal body weight for obese patients). ${ }^{2,3,11,12}$ Several factors can affect achievement of the goals with L-T4 therapy, including age, gender, other medical conditions, concurrent medications, patient compliance and genetic background. , 3, $, 9,11-15^{-1}$

Thyroid hormones exert their action by binding to two subtypes of nuclear receptors, which are known as thyroid hormone receptors (THR) $\alpha$ and $\beta .{ }^{16,17}$ These receptors are regulated by two genes: THR $\alpha$, which is located on chromosome 17 , and $T H R \beta$, which is located on chromosome $3{ }^{18,19} \mathrm{Rs} 939348$ is a THRa single nucleotide polymorphism that was found to be associated with increased systolic blood pressure and incidence of hypertension. ${ }^{20}$ On the other hand, thyroid gland secretion and growth are regulated by the action of TSH, which exerts its role through binding to TSH receptor (TSHR). ${ }^{21-23}$ Many studies have investigated the role of mutations in gene encoding TSHR in the development of different thyroid diseases. ${ }^{5,24-26}$ An association between TSHR gene SNP (rs2268458), which is located in intron 1, and higher incidence of Graves' disease was found by two studies conducted by Dechairo BM and colleagues and Yin X and colleagues. ${ }^{24,25,27} \mathrm{Gu}$ LQ and colleagues have investigated the role of TSHR SNP (rs2239610) in thyroid diseases and have found $\mathrm{CC}$ genotype to be associated with higher serum concentrations of fT4. ${ }^{28}$ In this study, we investigated the possible association between L-T4 doses in hypothyroid patients and THR $\alpha$ rs939348 SNP, and TSHR rs2268458 and rs2239610 SNPs.

\section{SUBJECTS AND METHODS}

\section{Subjects}

This is a cross-sectional study that was approved by Jordan University of Science and Technology In- stitutional Review Board (IRB) and was carried out in accordance with the Helsinki Declaration of 1975, with all amendments and revisions. A total of 228 unrelated patients with primary hypothyroidism were recruited from diabetes and endocrinology clinics at Ibn Al-Nafees Hospital and King Abdullah University Hospital. Patients included in this study are those who had completed puberty and had already been on stable doses of L-T4 for the previous 3 months. Excluded from this study were those with active neoplasm or history of neoplasm, severe liver dysfunction, severe-renal failure, diseases of the pituitary gland or hypothalamus including secondary hypothyroidism, major surgery within 2 weeks of enrolment, a severe psychiatric condition not related to hypothyroidism symptoms, GIT malabsorption diseases, pregnancy, alcohol abuse, concurrent medication that may interfere with thyroid hormone absorption or activation, critically ill patients, Hashimoto's thyroid disease and thyroidectomized patients on L-T4 treatment. Data collection was carried out by trained individuals and using information obtained either from subjects or their files. Written informed consents were obtained from all patients in accordance with the requirements of the IRB of Jordan University of Science and Technology.

\section{Measurements of body mass index (BMI) and blood pressure}

BMI was calculated as (weight in Kgs) / (height in meters $)^{2}$ as previously described..$^{29}$ For each patient, the ideal body weight (IBW) and adjusted body weight $(\mathrm{ABW})$ were calculated. The study population was divided into two groups: the low-dose group, which represented patients who were controlled on $<1.7 \mathrm{mcg} / \mathrm{kg} /$ day, and the high-dose group, which represented patients who were controlled on $\geq 1.7 \mathrm{mcg} /$ $\mathrm{kg} /$ day. This cut point was chosen based on previous studies $^{30}$ and because it represents the average L-T4 dose that is required by most hypothyroid patients. ${ }^{31}$ Blood pressure was measured by a trained healthcare professional using an arm cuff and a mercury column sphygmomanometer on the left arm after the patient had been in a resting period of at least 10 minutes in the supine position. Three measurements at one visit was averaged to evaluate the systolic and diastolic blood pressure. 


\section{Sample Collection and Handling}

Blood samples were collected from patients who matched the study criteria by a specialized licensed nurse. Blood $(5 \mathrm{~mL})$ was withdrawn and distributed into anticoagulant - free plain tube $(3 \mathrm{~mL})$ and evacuated EDTA tube $(2 \mathrm{~mL})$. The blood sample in the plain tube was centrifuged after 30 minutes of sampling and serum was isolated and stored at $-20^{\circ} \mathrm{C}$ and sent to Ibn Alnafees Hospital laboratory for biochemical analysis. Assays include TSH, fT3 and fT4. Assays were carried out using the AxSYM instrument (Abbott Laboratories, IL, U.S.A.) and commercially available diagnostic kits (Abbott Laboratories). Samples were assayed in duplicate and the mean of the paired results was determined. The blood collected in the EDTA tubes was used for DNA extraction.

\section{MOLECULAR ANALYSIS}

\section{DNA extraction}

The venous blood, which was collected in the evacuated EDTA tubes, was used for DNA extraction that was performed using the Promega wizard genomic DNA purification kit (Promega, Madison, WI, USA) according to the standard protocol provided by the manufacturer.

\section{PCR-RFLP}

Reference sequence and details of SNPs, PCR primers' design and restriction enzymes were obtained by searching the UCSC Genome Bioinformatics Site, Primer3 program and NEBcutter program, respectively. ${ }^{32-36}$ The location for the three SNPs, Rs 939348 on the THR $\alpha$ gene, and Rs2268458 and Rs2239610 on the TSHR gene, is described in Table 1. The genomic DNA was amplified using the following steps: dena- turation of double stranded genomic DNA at $94^{\circ} \mathrm{C}$ for 5 minutes, DNA amplification using 30 cycles. Each cycle consists of: denaturation at $94^{\circ} \mathrm{C}$ for 30 s, annealing for $30 \mathrm{~s}$, extension at $72^{\circ} \mathrm{C}$ for $40 \mathrm{~s}$, final elongation at $72^{\circ} \mathrm{C}$ for 7 minutes, and ending reaction at $4^{\circ} \mathrm{C}$. Table 1 summarizes restriction enzymes and restricted fragments for all SNPs. The restriction enzyme digestion was carried out in $20 \mu \mathrm{l}$ containing 1 unit of enzyme and $10 \mu \mathrm{l}$ of PCR product and incubated at $37^{\circ} \mathrm{C}$ for overnight. All enzymes were obtained from Fermentas ( $\mathrm{GmbH}$, St. Leon-Rot, Germany). PCR products and digested fragments were detected using electrophoresis on $2 \%$ agarose.

\section{Statistical Analysis}

Data was analyzed using the SPSS version 17 package (SPSS Inc, Chicago, USA) for Windows. Continuous variables were expressed as mean (standard deviation) and the differences were accomplished by comparison via student's unpaired 2-sided t-test or one way ANOVA as appropriate. Discrete variables were expressed as counts and frequencies and were compared using the chi-square test. If $\mathrm{N}<5$, exact Fisher statistic was used. The genotype distributions of SNPs were analyzed in agreement with the HardyWeinberg equilibrium. A significant difference is considered at $\mathrm{P}<0.05$.

\section{RESULTS}

The mean age of patients was 39.4 years, male to female ratio was $1: 8$ and the mean BMI $\left(\mathrm{kg} / \mathrm{m}^{2}\right)$ was 29.3. Of the 228 participants, $23.3 \%$ were dyslipidemic, $17.5 \%$ were diabetic and $23.2 \%$ were hypertensive (Table 2). The average duration of disease was 4.8 years. About $44 \%$ of the participants had a family history of thyroid disorders (Table 2).

Table 1. The PCR primers, restriction enzymes and sizes of the amplified and digested fragments of the examined SNPs

\begin{tabular}{|c|c|c|c|c|}
\hline SNP & $\begin{array}{l}\text { PCR product } \\
\text { (bp) }\end{array}$ & Primers & $\begin{array}{c}\text { Restriction } \\
\text { enzyme }\end{array}$ & $\begin{array}{l}\text { Restricted fragments } \\
\text { (bp) }\end{array}$ \\
\hline Rs939348 & 190 & $\begin{array}{l}\text { F: 5’CCTGTGTCTCCCAGCTTAGG ‘3 } \\
\text { R: 5'CCACCAGACTCACAGCCTCT ‘3 }\end{array}$ & MesI & $\begin{array}{c}\text { C allele } 190 \\
\text { T allele } 48 \& 142\end{array}$ \\
\hline Rs2268458 & 162 & $\begin{array}{l}\text { F: 5'CTAACCAGCAGAGGGAGCAC'3 } \\
\text { R: 5'CCACTGCTTAAAGCCCAGAT '3 }\end{array}$ & AluI & $\begin{array}{c}\text { T allele } 162 \\
\text { C allele } 100 \& 62\end{array}$ \\
\hline Rs2239610 & 172 & $\begin{array}{l}\text { F: 5'CCAGAGATCAAGGGCATCTG ‘3 } \\
\text { R: 5'CCAAGTGTGGGCGATTAAGT '3 }\end{array}$ & NlaIV & $\begin{array}{c}\text { G allele } 172 \\
\text { C allele } 142 \& 30\end{array}$ \\
\hline
\end{tabular}


Table 2. Characteristics of the hypothyroid patients $(\mathrm{N}=228)$

\begin{tabular}{|c|c|c|c|}
\hline \multirow{2}{*}{$\begin{array}{l}\text { Variable } \\
\text { Age: mean (SD) }\end{array}$} & & \multicolumn{2}{|c|}{ Number of hypothyroid patients $N(\%)$ or mean (SD) } \\
\hline & & 39.439 & $(14.071)$ \\
\hline \multirow[t]{2}{*}{ Gender } & Male & 15 & $(6.6 \%)$ \\
\hline & Female & 213 & $(93.4 \%)$ \\
\hline \multirow[t]{2}{*}{ Smoker } & Yes & 20 & $(8.8 \%)$ \\
\hline & No & 208 & $(91.2 \%)$ \\
\hline \multicolumn{2}{|l|}{ BMI $\left(\mathrm{kg} / \mathrm{m}^{2}\right):$ mean $(\mathrm{SD})$} & 29.334 & $(6.515)$ \\
\hline BMI categories: & Normal weight & 56 & $(24.6 \%)$ \\
\hline & Overweight & 75 & $(32.9 \%)$ \\
\hline & Obese & 55 & $(24.1 \%)$ \\
\hline & Severely obese & 42 & $(18.4 \%)$ \\
\hline \multicolumn{2}{|l|}{ Waist circumference $(\mathrm{cm})$ : mean (SD) } & 90.766 & $(18.355)$ \\
\hline \multirow[t]{2}{*}{ Central obesity: } & Yes & 119 & $(52.2 \%)$ \\
\hline & No & 109 & $(48.8 \%)$ \\
\hline \multirow[t]{2}{*}{ Dyslipidemia } & Yes & 54 & $(23.7 \%)$ \\
\hline & No & 174 & $(76.3 \%)$ \\
\hline \multirow[t]{2}{*}{ Hypertension } & Yes & 53 & $(23.2 \%)$ \\
\hline & No & 175 & $(76.8 \%)$ \\
\hline \multirow[t]{2}{*}{ Diabetes Mellitus } & Yes & 40 & $(17.5 \%)$ \\
\hline & No & 188 & $(82.5 \%)$ \\
\hline \multirow[t]{2}{*}{ Coronary Heart Disease } & Yes & 14 & $(6.1 \%)$ \\
\hline & No & 214 & $(93.9 \%)$ \\
\hline \multirow[t]{2}{*}{ Osteoporosis } & Yes & 24 & $(10.5 \%)$ \\
\hline & No & 204 & $(89.5 \%)$ \\
\hline \multirow[t]{2}{*}{ Family history of Diabetes Mellitus } & Yes & 139 & $(61 \%)$ \\
\hline & No & 89 & $(39 \%)$ \\
\hline \multirow[t]{2}{*}{ Family history of Thyroid Disorders } & Yes & 101 & $(44.3 \%)$ \\
\hline & No & 127 & $(55.7 \%)$ \\
\hline \multirow[t]{2}{*}{ Family history of Coronary Heart Disease } & Yes & 76 & $(33.3 \%)$ \\
\hline & No & 152 & $(66.7 \%)$ \\
\hline \multirow[t]{3}{*}{ Duration of illness (years): mean (SD) } & & 4.843 & $(5.177)$ \\
\hline & $<10$ years & 188 & $(82.5 \%)$ \\
\hline & $\geq 10$ years & 40 & $(17.5 \%)$ \\
\hline \multicolumn{2}{|l|}{ TSH (mIU/L): mean (SD) } & 2.129 & $(1.263)$ \\
\hline \multicolumn{2}{|l|}{ fT3 (pg/mL): mean (SD) } & 2.458 & $(0.597)$ \\
\hline \multicolumn{2}{|l|}{ fT4 (ng/dL): mean (SD) } & 1.148 & $(0.324)$ \\
\hline \multicolumn{2}{|l|}{ L-T4 daily dose (mcg/kg/day): mean (SD) } & 1.381 & $(0.655)$ \\
\hline \multicolumn{2}{|l|}{$\mathrm{SBP}(\mathrm{mmHg})$ : mean $(\mathrm{SD})$} & 117.697 & $(12.187)$ \\
\hline \multicolumn{2}{|l|}{$\mathrm{DBP}(\mathrm{mmHg}):$ mean $(\mathrm{SD})$} & 75.351 & $(8.544)$ \\
\hline
\end{tabular}


The genotype and allele frequencies of examined SNPs were determined. For rs939348 (C/T), the frequency of wild type $\mathrm{C}$ allele was $70 \%$, whereas for rs2268458 (T/C), the frequency of the wild type $\mathrm{T}$ allele was $76 \%$ and for $\mathrm{rs} 2239610(\mathrm{G} / \mathrm{C})$ the wild type $\mathrm{G}$ allele frequency was $74 \%$. The distribution of rs 939348 genotypes was $50.9 \%$ for CC, $37.3 \%$ for CT and $11.8 \%$ for TT, whereas for rs 2268458 , the distribution was $59.2 \%$ for TT, $33.3 \%$ for TC and $7.5 \%$ for CC. For rs2239610, the distribution of the genotypes was $58.3 \%$ for GG, $32.3 \%$ for GC and $9.4 \%$ for CC.

The clinical and biochemical characteristics of rs939348, rs2268458 and rs2239610 genotypes were studied (Tables 3-5). There was no significant cor-

Table 3. Means and standard deviations of total hypothyroid patients according to genotypes and alleles of Rs939348

\begin{tabular}{|c|c|c|c|c|c|c|c|}
\hline \multirow[b]{2}{*}{ Variable } & \multicolumn{3}{|c|}{ THR $\alpha$ rs939348 } & \multirow{2}{*}{$\begin{array}{l}\text { P-value } \\
\text { one way } \\
\text { ANOVA }\end{array}$} & \multicolumn{2}{|c|}{ Alleles } & \multirow{2}{*}{$\begin{array}{c}\text { P-value } \\
\text { un-paired } \\
\text { t-test }\end{array}$} \\
\hline & $\begin{array}{c}\mathrm{CC} \\
\mathrm{N}=116\end{array}$ & $\begin{array}{c}\mathrm{CT} \\
\mathrm{N}=85\end{array}$ & $\begin{array}{c}\mathrm{TT} \\
\mathrm{N}=27\end{array}$ & & $\begin{array}{c}\mathrm{C} \\
\mathrm{N}=317\end{array}$ & $\begin{array}{c}\mathrm{T} \\
\mathrm{N}=139\end{array}$ & \\
\hline $\begin{array}{l}\text { Age, years } \\
\text { Mean (SD) }\end{array}$ & $40.48(13.96)$ & $39.64(12.78)$ & $33.89(15.11)$ & 0.079 & $40.25(13.61)$ & $37.4(13.91)$ & 0.413 \\
\hline $\begin{array}{l}\text { BMI } \\
\text { Mean (SD) }\end{array}$ & $29.74(7.02)$ & $29.6(5.86)$ & $26.6(5.63)$ & 0.071 & $30.10(6.44)$ & $29.00(5.59)$ & 0.072 \\
\hline $\begin{array}{l}\text { Waist circum, cm } \\
\text { Mean (SD) }\end{array}$ & 91.65 (19.16) & $92.4(16.65)$ & $81.63(17.90)$ & 0.021 & 91.84 (18.47) & 88.21 (17.81) & 0.510 \\
\hline $\begin{array}{l}\text { Duration of illness, years } \\
\text { Mean (SD) }\end{array}$ & $4.62(4.72)$ & $4.8(5.33)$ & $5.61(6.46)$ & 0.671 & $4.69(4.88)$ & $5.15(5.76)$ & 0.377 \\
\hline $\mathrm{TSH}(\mathrm{mIU} / \mathrm{L})$ & $2.16(1.27)$ & $2.13(1.20)$ & $1.96(1.42)$ & 0.759 & $2.15(1.25)$ & $2.06(1.28)$ & 0.490 \\
\hline fT3 $(\mathrm{pg} / \mathrm{mL})$ & $2.45(0.57)$ & $2.48(0.64)$ & $2.36(0.57)$ & 0.654 & $2.46(0.59)$ & $2.44(0.61)$ & 0.755 \\
\hline fT4 (ng/dL) & $1.15(0.35)$ & $1.12(0.27)$ & $1.17(0.35)$ & 0.707 & $1.14(0.33)$ & $1.14(0.30)$ & 0.995 \\
\hline $\mathrm{L}-\mathrm{T} 4$ daily dose $(\mathrm{mcg} / \mathrm{kg} / \mathrm{day})$ & $1.30(0.59)$ & $1.45(0.73)$ & $1.49(0.57)$ & 0.167 & $1.31(0.62)$ & $1.48(0.67)$ & 0.014 \\
\hline $\mathrm{SBP}(\mathrm{mmHg})$ & $117.33(11.54)$ & $118.29(13.28)$ & $116.67(11.43)$ & 0.783 & $117.58(12.0)$ & $117.66(12.5)$ & 0.952 \\
\hline DBP (mmHg) & $74.87(8.37)$ & $75.88(8.66)$ & 75.37 (9.08) & 0.710 & 75.14 (8.44) & $75.68(8.76$ & 0.534 \\
\hline
\end{tabular}

Table 4. Means and standard deviations of total hypothyroid patients according to genotypes and alleles of Rs 2268458

\begin{tabular}{|c|c|c|c|c|c|c|c|}
\hline \multirow[t]{2}{*}{ Variable } & \multicolumn{3}{|c|}{ TSHR rs2268458 } & \multirow{2}{*}{$\begin{array}{l}\text { P-value } \\
\text { one way } \\
\text { ANOVA }\end{array}$} & \multicolumn{2}{|c|}{ Alleles } & \multirow{2}{*}{$\begin{array}{c}\text { P-value } \\
\text { Un-paired } \\
\text { t-test }\end{array}$} \\
\hline & $\begin{array}{c}\text { TT } \\
\mathrm{N}=135\end{array}$ & $\begin{array}{c}\mathrm{TC} \\
\mathrm{N}=76\end{array}$ & $\begin{array}{c}\mathrm{CC} \\
\mathrm{N}=17\end{array}$ & & $\begin{array}{c}\mathrm{T} \\
\mathrm{N}=346\end{array}$ & $\begin{array}{c}C \\
N=110\end{array}$ & \\
\hline $\begin{array}{l}\text { Age, years } \\
\text { Mean (SD) }\end{array}$ & $39.3(13.73)$ & $39.46(14.22)$ & $39.76(12.7)$ & 0.990 & $39.33(13.8)$ & $39.55(13.6)$ & 0.883 \\
\hline $\begin{array}{l}\text { BMI } \\
\text { Mean (SD) }\end{array}$ & $29.09(6.28)$ & $29.90(7.17)$ & $28.47(5.04)$ & 0.590 & $29.27(6.48)$ & $29.46(6.58)$ & 0.789 \\
\hline $\begin{array}{l}\text { Waist circum, cm } \\
\text { Mean (SD) }\end{array}$ & $90.87(18.59)$ & $91.54(18.58)$ & $86.18(15.47)$ & 0.550 & $91.01(18.53)$ & $89.88(17.72)$ & 0.573 \\
\hline $\begin{array}{l}\text { Duration of illness, years } \\
\text { Mean (SD) }\end{array}$ & $4.7(4.60)$ & $4.6(5.44)$ & $6.14(7.79)$ & 0.553 & $4.73(4.78)$ & $5.1(6.21)$ & 0.482 \\
\hline TSH (mIU/L) & $2.19(1.25)$ & $1.93(1.27)$ & $2.27(1.31)$ & 0.464 & $2.14(1.25)$ & $2.07(1.28)$ & 0.617 \\
\hline fT3 (pg/mL) & $2.47(0.63)$ & $2.43(0.566)$ & $2.35(0.466)$ & 0.684 & $2.46(0.61)$ & $2.41(0.53)$ & 0.374 \\
\hline fT4 (ng/dL) & $1.18(0.33)$ & $1.09(0.31)$ & $1.09(0.306)$ & 0.152 & $1.16(0.32)$ & $1.09(0.31)$ & 0.063 \\
\hline L-T4 daily dose (mcg/kg/day) & $1.38(0.65)$ & $1.32(0.611)$ & $1.64(0.779)$ & 0.192 & $1.37(0.64)$ & $1.42(0.67)$ & 0.441 \\
\hline $\mathrm{SBP}(\mathrm{mmHg})$ & $117.85(13.26)$ & $117.04(10.71)$ & $118.24(11.85)$ & 0.877 & $117.67(12.62)$ & $117.4(10.61)$ & 0.843 \\
\hline $\mathrm{DBP}(\mathrm{mmHg})$ & $75.33(9.16)$ & $74.93(7.68)$ & $76.76(7.27)$ & 0.728 & $75.24(8.83)$ & $75.5(7.54)$ & 0.786 \\
\hline
\end{tabular}


Table 5. Means and standard deviations of total hypothyroid patients according to genotypes and alleles of Rs 2239610

\begin{tabular}{|c|c|c|c|c|c|c|c|}
\hline \multirow[t]{2}{*}{ Variable } & \multicolumn{3}{|c|}{ TSHR rs2239610 } & \multirow{2}{*}{$\begin{array}{l}\text { P-value } \\
\text { one way } \\
\text { ANOVA }\end{array}$} & \multicolumn{2}{|c|}{ Alleles } & \multirow{2}{*}{$\begin{array}{c}\text { P-value } \\
\text { Un-paired } \\
\text { t-test }\end{array}$} \\
\hline & $\begin{array}{c}\text { GG } \\
\mathrm{N}=133\end{array}$ & $\begin{array}{c}\text { GC } \\
\mathrm{N}=73\end{array}$ & $\begin{array}{c}\mathrm{CC} \\
\mathrm{N}=22\end{array}$ & & $\begin{array}{c}\mathrm{G} \\
\mathrm{N}=339\end{array}$ & $\begin{array}{c}\mathrm{C} \\
\mathrm{N}=117\end{array}$ & \\
\hline $\begin{array}{l}\text { Age, years } \\
\text { Mean (SD) }\end{array}$ & $39.44(13.58)$ & $39.66(14.85)$ & $38.14(11.44)$ & 0.900 & $39.45(13.8)$ & $39.08(13.60)$ & 0.784 \\
\hline $\begin{array}{l}\text { BMI } \\
\text { Mean (SD) }\end{array}$ & $29.09(6.37)$ & $29.97(7.10)$ & $28.49(5.22)$ & 0.533 & $29.28(6.52)$ & $29.41(6.46)$ & 0.846 \\
\hline $\begin{array}{l}\text { Waist circum, cm } \\
\text { Mean (SD) }\end{array}$ & $91.35(18.89)$ & $90.34(17.40)$ & $88.36(18.5)$ & 0.761 & $91.13(18.54)$ & $89.59(17.72)$ & 0.435 \\
\hline $\begin{array}{l}\text { Duration of illness, years } \\
\text { Mean (SD) }\end{array}$ & $4.91(5.09)$ & $4.22(4.627)$ & $6.73(6.98)$ & 0.226 & $4.7(4.98)$ & $5.03(5.66)$ & 0.628 \\
\hline TSH (mIU/L) & $2.15(1.269)$ & $2.10(1.263)$ & $2.06(1.273)$ & 0.930 & $2.14(1.26)$ & $2.08(1.25)$ & 0.683 \\
\hline $\mathrm{fT} 3(\mathrm{pg} / \mathrm{mL})$ & $2.43(0.59)$ & $2.51(0.629)$ & $2.35(0.575)$ & 0.498 & $2.45(0.598)$ & $2.45(0.60)$ & 0.986 \\
\hline $\mathrm{fT} 4(\mathrm{ng} / \mathrm{dL})$ & $1.16(0.33)$ & $1.12(0.319)$ & $1.09(0.307)$ & 0.486 & $1.15(0.329)$ & $1.11(0.312)$ & 0.197 \\
\hline L-T4 daily dose (mcg/kg/day) & $1.40(0.66)$ & $1.28(0.621)$ & $1.54(0.668)$ & 0.219 & $1.38(0.65)$ & $1.38(0.64)$ & 0.964 \\
\hline $\mathrm{SBP}(\mathrm{mmHg})$ & $117.86(13.17)$ & $117.05(10.43)$ & $117.95(11.61)$ & 0.895 & $117.68(12.60)$ & $117.3(10.79)$ & 0.824 \\
\hline $\mathrm{DBP}(\mathrm{mmHg})$ & $75.3(8.87)$ & $75.27(8.03)$ & $75.45(8.57)$ & 0.996 & $75.29(8.67)$ & $75.34(8.16)$ & 0.959 \\
\hline
\end{tabular}

relation between rs2268458 and rs2239610 genotypes and L-T4 dose or any of the studied biochemical and clinical parameters (Tables 4-5). A significant difference between the $T H R \alpha$ rs939348 genotypes and waist circumference $(\mathrm{P}=0.021)$ was detected, where the TT genotype was associated with less waist circumference (Table 3). In addition, a significant correlation between L-T4 daily dose $(\mathrm{mcg} / \mathrm{kg} /$ day $)$ and the two alleles of rs939348 was found $(\mathrm{P}=0.014)$, where $\mathrm{T}$ allele carrier patients required significantly higher doses of L-T4 for control of hypothyroidism (Table 3).

The patients were also divided into two groups based on current replacement L-T4 dose: low dose group $(<1.7 \mathrm{mcg} / \mathrm{kg} / \mathrm{day}, \mathrm{n}=154)$ and high dose group $(\geq 1.7 \mathrm{mcg} / \mathrm{kg} / \mathrm{day}, \mathrm{n}=74)$. The dose of T4 was associated with lower $\mathrm{BMI}(\mathrm{P}=0.034)$, WC $(\mathrm{P}=0.018)$ and TSH $(\mathrm{P}=0.001)$, and higher fT4 levels $(\mathrm{P}=0.001$; Figure 1). Other parameters including age, presence of dyslipidemia, hypertension, diabetes mellitus, systolic and diastolic blood pressures, and the distribution of the genotypes of the three examined SNPS were not different between the two dosing groups.

\section{DISCUSSION}

In this study, we hypothesized that there might be an association between polymorphisms in the $T H R$ and TSHR genes and the replacement doses of L-T4. The role of thyroid hormones receptors (THR $\alpha$ and THR $\beta$ ) in mediating the functions of the thyroid gland is well documented. ${ }^{16,17}$ In addition, thyroid gland functions are regulated by the action of TSH, which exerts its role through binding to TSHR. ${ }^{21-23}$ Many studies have investigated the role of mutations in genes encoding TSHR and THR in the development of different thyroid diseases., ${ }^{54-26}$

This study showed no association between TSHR SNPs rs2268458 and rs2239610, and the replacement doses of L-T4. Additionally, the current study found no correlation between these polymorphisms and the studied biochemical and clinical markers including thyroid function tests (TSH, fT3 and fT4). A previous study by Gu LQ and colleagues found that rs 2239610 $\mathrm{CC}$ genotype was associated with higher serum concentrations of fT $4 .{ }^{28}$ Another study by Louwerens et al. detected a modest effect for TSHR-Asp727Glu polymorphism on fatigue in patients with differentiated thyroid carcinoma. ${ }^{5}$

In our study, we found a positive correlation between the THR $\alpha$ rs 939348 polymorphism and both L-T4 replacement doses and central obesity. On the other hand, our study showed lack of association 
A.

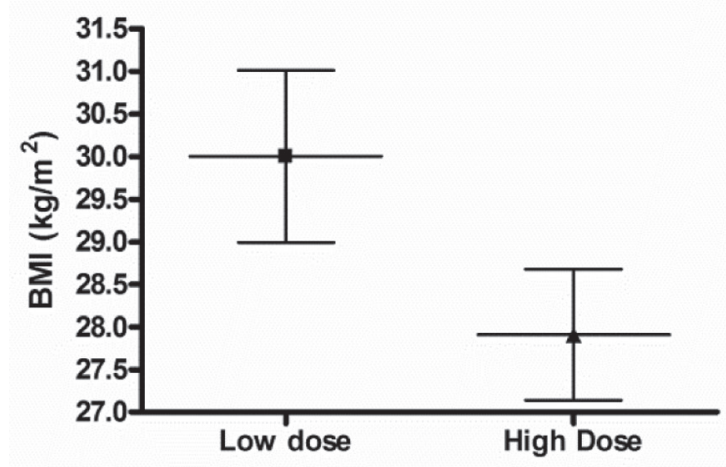

C.

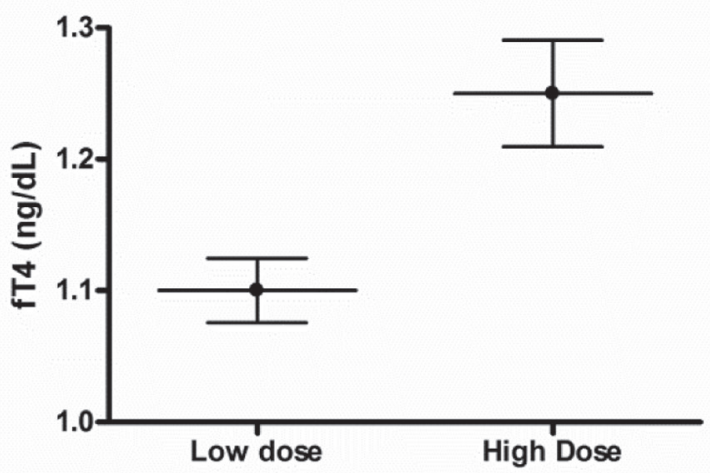

B.

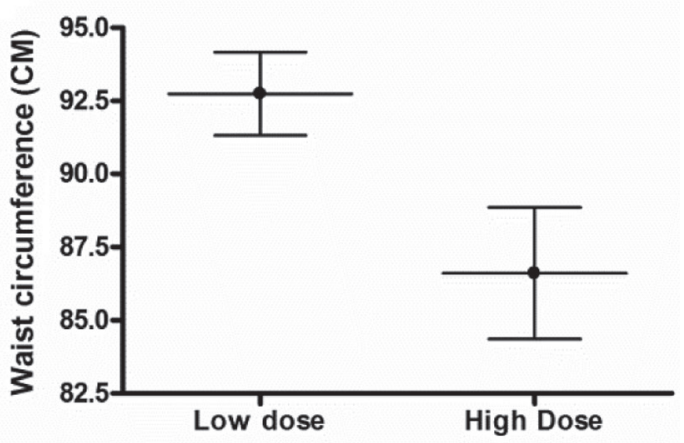

D.

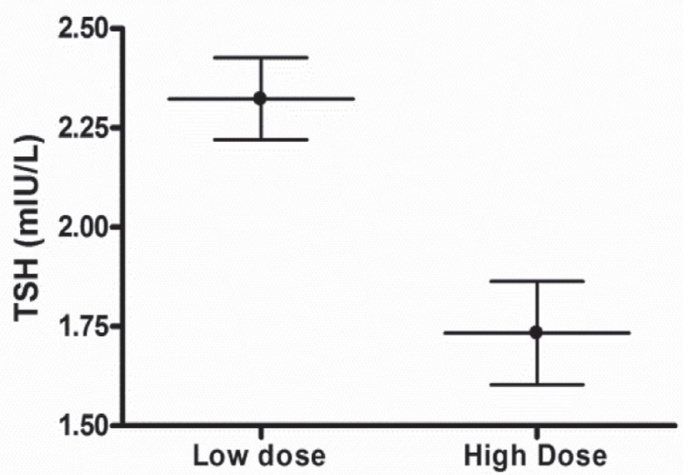

Figure 1. Patients were divided into two groups: low-dose group, which represented patients who were controlled on $<1.7 \mathrm{mcg} / \mathrm{kg} /$ day, and high-dose group, which represented patients who were controlled on $\geq 1.7 \mathrm{mcg} / \mathrm{kg} /$ day. Levothyroxine (L-T4) dose was associated with lower BMI (A), waist circumference (B), and TSH (D) and higher free T4 (fT4; C) among hypothyroid patients.

between THR $\alpha$ rs939348 and elevated blood pressure, yet an association was shown in Goumidi L and colleagues' study among US populations. ${ }^{20}$ This could be due to the small number of hypertensive patients included in the present study $(\mathrm{n}=53)$.

In the current study, a positive association that was found between central obesity and THR $\alpha$ rs939348 polymorphism suggests that this SNP could have a role in development of metabolic syndrome, which is known to be a risk factor for coronary heart disease. ${ }^{15,37}$ The rs939348 SNP was studied in addition to a wide range of other SNPs by Arnaud-Lopez L. and colleagues and a positive correlation was detected among its variations and TSH serum level. ${ }^{24}$

Factors other than genetic variations were shown to be associated with the dose of L-T4. For example, high L-T4 dose was associated with lower BMI, lower body weight and TSH and higher levels of fT4. These results are in agreement with the previous knowledge about L-T4 treatment among hypothyroid patients ${ }^{38}$ and generally support our genetic findings.

The clinical consequence of this study is the proposal that hypothyroidism patients with rs 939348 TT genotypes might need to be identified prior to treatments, as they are expected to require higher doses of L-T4. More studies are required in other populations to generalize the present finding.

In conclusion, hypothyroid patients with rs 939348 TT genotype had more central obesity and those who carry the $\mathrm{T}$ allele needed higher replacement doses of L-T4. We therefore suggest that this SNP might have a role in control of both hypothyroidism, of metabolic syndrome and its associated risk and of resistance to L-T4 therapy. 


\section{FUNDING}

The study was funded by grant no. 168/2010 from the Deanship of Research of the Jordan University of Science and Technology.

\section{CONFLICT OF INTEREST}

None to declare.

\section{REFERENCES:}

1. Todd CH, 2009 Management of thyroid disorders in primary care: challenges and controversies. Postgrad Med J 85: 655-659.

2. Baskin HJ, Cobin RH, Duick DS, et al, 2002 American Association of Clinical Endocrinologists medical guidelines for clinical practice for the evaluation and treatment of hyperthyroidism and hypothyroidism. Endocr Pract 8: 457-469.

3. Vaidya B, Pearce SH, 2008 Management of hypothyroidism in adults. BMJ 337: a801.

4. Zhang J, Lazar MA, 2000 The mechanism of action of thyroid hormones. Annu Rev Physiol 62: 439-466.

5. Louwerens M, Appelhof BC, Verloop H, et al, 2012 Fatigue and fatigue-related symptoms in patients treated for different causes of hypothyroidism. Eur J Endocrinol 167: 809-815.

6. Peeters RP, van der Deure WM, Visser TJ, 2006 Genetic variation in thyroid hormone pathway genes; polymorphisms in the TSH receptor and the iodothyronine deiodinases. Eur J Endocrinol 155: 655-662.

7. Zulewski H, Muller B, Exer P, Miserez AR, Staub JJ, 1997 Estimation of tissue hypothyroidism by a new clinical score: evaluation of patients with various grades of hypothyroidism and controls. J Clin Endocrinol Metab 82: 771-776.

8. Bunevicius R, Kazanavicius G, Zalinkevicius R, Prange AJ Jr, 1999 Effects of thyroxine as compared with thyroxine plus triiodothyronine in patients with hypothyroidism. N Engl J Med 340: 424-429.

9. Checchi S, Montanaro A, Pasqui L, et al, 2008 Lthyroxine requirement in patients with autoimmune hypothyroidism and parietal cell antibodies. J Clin Endocrinol Metab 93: 465-469.

10. Escobar-Morreale HF, Botella-Carretero JI, GomezBueno M, et al, 2005 Thyroid hormone replacement therapy in primary hypothyroidism: a randomized trial comparing L-thyroxine plus liothyronine with Lthyroxine alone. Ann Intern Med 142: 412-424.

11. Jonklaas J, 2009 Gender and age differences in levothyroxine dose requirement. Endocrine Practice 15: 1-23.

12. Levothyroxine drug information provided by Lexi-Comp 2010 [cited 201018 June 2010].

13. Peeters RP, van Toor H, Klootwijk W, et al, 2003
Polymorphisms in thyroid hormone pathway genes are associated with plasma TSH and iodothyronine levels in healthy subjects. J Clin Endocrinol Metab 88: 28802888.

14. Kim BW, Bianco AC, 2009 For some, L-thyroxine replacement might not be enough: a genetic rationale. J Clin Endocrinol Metab 94: 1521-1523.

15. Al-Azzam SI, Alkhateeb AM, Al-Azzeh O, Alzoubi KH, Khabour OF, 2013 The Role of Type II Deiodinase Polymorphisms in Clinical Management of Hypothyroid Patients Treated with Levothyroxine. Exp Clin Endocrinol Diabetes 121: 300-305.

16. Lin JZ, Sieglaff DH, Yuan C, et al, 2013 Gene specific actions of thyroid hormone receptor subtypes. PLoS One 8: e52407.

17. Brent GA, 2012 Mechanisms of thyroid hormone action. J Clin Invest 122: 3035-3043.

18. Peeters RP, van der Deure WM, Visser TJ, 2006 Genetic variation in thyroid hormone pathway genes; polymorphisms in the TSH receptor and the iodothyronine deiodinases. Eur J Endocrinol 155: 655-662.

19. Rebai M, Kallel I, Rebai A, 2012 Genetic features of thyroid hormone receptors. J Genet 91: 367-374.

20. Goumidi L, Gauthier K, Legry V, et al, 2011 Association between a thyroid hormone receptor-alpha gene polymorphism and blood pressure but not with coronary heart disease risk. Am J Hypertens 24: 1027-1034.

21. Schaffler A, 2010 Hormone replacement after thyroid and parathyroid surgery. Dtsch Arztebl Int 107: 827-834.

22. Lizcano F, Rodriguez JS, 2011 Thyroid hormone therapy modulates hypothalamo-pituitary-adrenal axis. Endocr J 58: 137-142.

23. Katzung BG, Trevor AJ, 2010 Basic \& Clinical Pharmacology. McGraw-Hill Medical.

24. Arnaud-Lopez L, Usala G, Ceresini G, et al, 2008 Phosphodiesterase $8 \mathrm{~B}$ gene variants are associated with serum TSH levels and thyroid function. Am J Hum Genet 82: 1270-1280.

25. Dechairo BM, Zabaneh D, Collins J, et al, 2005 Association of the TSHR gene with Graves' disease: the first disease specific locus. Eur J Hum Genet 13: 1223-1230.

26. Cerbone M, Agretti P, De Marco G, et al, 2013 Nonautoimmune subclinical hypothyroidism due to a mutation in TSH receptor: report on two brothers. Ital J Pediatr 39: 5 .

27. Yin X, Latif R, Bahn R, Tomer Y, Davies TF, 2008 Influence of the TSH receptor gene on susceptibility to Graves' disease and Graves' ophthalmopathy. Thyroid 18: 1201-1206.

28. Gu LQ, Zhu W, Zhao SX, et al, 2010 Clinical associations of the genetic variants of CTLA-4, Tg, TSHR, PTPN22, PTPN12 and FCRL3 in patients with Graves' disease. Clin Endocrinol (Oxf) 72: 248-255.

29. Gharibeh MY, Al Tawallbeh GM, Abboud MM, et al, 2010 Correlation of plasma resistin with obesity and insulin resistance in type 2 diabetic patients. Diabetes 
Metab 36: 443-449.

30. Al-Azzam SI, Alkhateeb AM, Al-Azzeh O, Alzoubi KH, Khabour OF, 2013 The role of type II deiodinase polymorphisms in clinical management of hypothyroid patients treated with levothyroxine. Exp Clin Endocrinol Diabetes 121: 300-305.

31. Hueston WJ, 2001 Treatment of hypothyroidism. Am Fam Physician 64: 1717-1724.

32. dbSNP provided by Medline database

33. The human genome browser at UCSC Genome, 2000 USCS Genome Bioinformatics.

34. Rozan S, Skaletsky H 2000 Primer3 on the WWW for general users and for biologist programmers. In:
Krawetz S, Misener S (eds) Bioinformatics Methods and Protocols: Methods in Molecular Biology, Humana Press, Totowa, NJ, pp, 365-386.

35. Vincze T, Posfai J, Roberts RJ, 2003 NEBcutter: A program to cleave DNA with restriction enzymes. Nucleic Acids Res 31: 3688-3691.

36. Restriction Mapper: Maps sites for restriction enzymes, a.k.a. restriction endonucleases, in DNA sequences.

37. Ruhla S, Weickert MO, Arafat AM, et al, 2010 A high normal TSH is associated with the metabolic syndrome. Clin Endocrinol (Oxf) 72: 696-701.

38. Pearce EN, 2012 Thyroid hormone and obesity. Curr Opin Endocrinol Diabetes Obes 19: 408-413. 